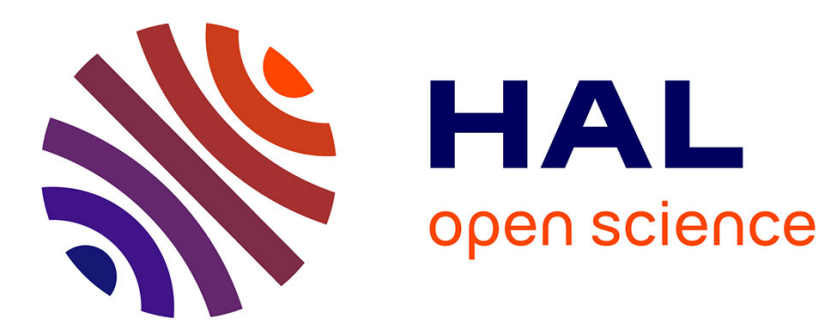

\title{
Investigating endodontic sealers eugenol and hydrocortisone roles in modulating the initial steps of inflammation
}

Charlotte Jeanneau, Thomas Giraud, Jean-Louis Milan, Imad About

\section{To cite this version:}

Charlotte Jeanneau, Thomas Giraud, Jean-Louis Milan, Imad About. Investigating endodontic sealers eugenol and hydrocortisone roles in modulating the initial steps of inflammation. Clinical Oral Investigations, 2019, 24 (2), pp.639-647. 10.1007/s00784-019-02957-2 . hal-02529087

\section{HAL Id: hal-02529087 \\ https://hal.science/hal-02529087}

Submitted on 2 Apr 2020

HAL is a multi-disciplinary open access archive for the deposit and dissemination of scientific research documents, whether they are published or not. The documents may come from teaching and research institutions in France or abroad, or from public or private research centers.
L'archive ouverte pluridisciplinaire HAL, est destinée au dépôt et à la diffusion de documents scientifiques de niveau recherche, publiés ou non, émanant des établissements d'enseignement et de recherche français ou étrangers, des laboratoires publics ou privés. 


\section{Clinical Oral Investigations}

\section{Investigating endodontic sealers eugenol and hydrocortisone roles in modulating the initial steps of inflammation \\ --Manuscript Draft--}

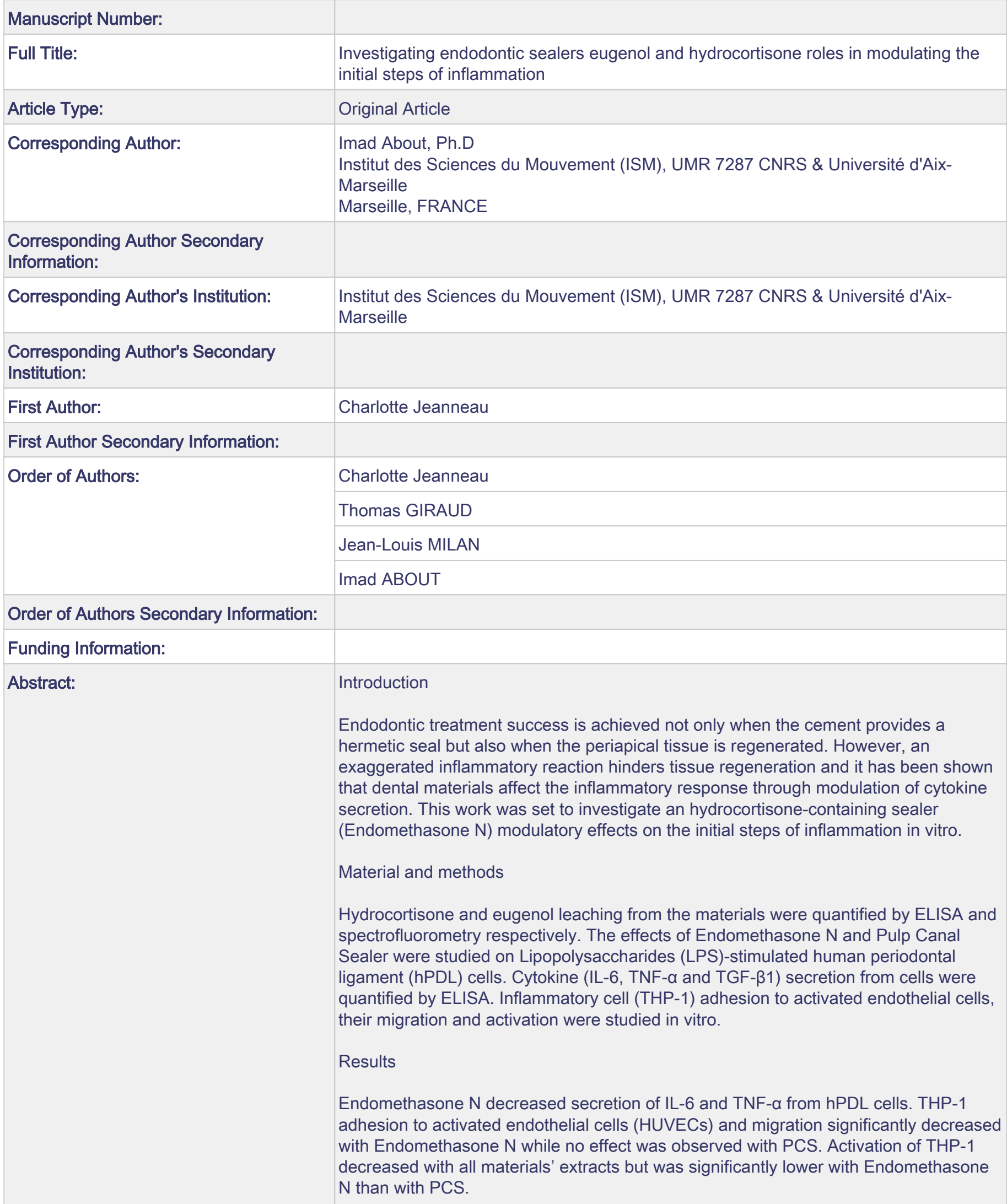




\section{Conclusion}

These results performed in vitro show that Endomethasone $\mathrm{N}$ has higher antiinflammatory effects than PCS. Our results show that this effect is due to the presence of hydrocortisone in Endomethasone $\mathrm{N}$

\section{Clinical Relevance}

It is the presence of hydrocortisone in Endomethasone $\mathrm{N}$ which is responsible for its local anti-inflammatory effects rather than eugenol.

Suggested Reviewers: 


\section{Investigating endodontic sealers eugenol and hydrocortisone roles in modulating the initial steps of inflammation}

Charlotte JEANNEAU ${ }^{1}$, Thomas GIRAUD ${ }^{1,2}$, Jean-Louis MILAN ${ }^{1}$, and Imad ABOUT ${ }^{1 *}$

${ }^{1}$ Aix Marseille Univ, CNRS, ISM, Inst Movement Sci, Marseille, France.

${ }^{2}$ Service d'Odontologie, Hôpital Timone, APHM, Marseille, France.

*Corresponding author:

Prof. Imad ABOUT :

Institut des Sciences du Mouvement (ISM)

UMR 7287 CNRS \& Université d'Aix-Marseille

Faculté d'Odontologie,

27 Bd Jean Moulin

13385 MARSEILLE cedex 5

France

Tel: 0486136859

Fax: 0486136840

email: $\underline{\text { imad.about@univ-amu.fr }}$

\section{Keywords}

Endodontic sealer, periodontal ligament inflammation, zinc oxide eugenol, hydrocortisone.

\section{Acknowledgments}

The authors thank Dr. Jean-Charles GARDON for providing the teeth. This work was supported by Aix-Marseille University and CNRS. The authors deny any conflicts of interest. 


\section{Abstract}

Introduction. Endodontic treatment success is achieved not only when the cement provides a hermetic seal but also when the injured periapical tissue is regenerated. However, an exaggerated inflammatory reaction hinders tissue regeneration and it has been shown that dental materials affect the inflammatory response through modulation of cytokine secretion. This work was set to investigate a hydrocortisone-containing sealer (Endomethasone $\mathrm{N}$ ) modulatory effects on the initial steps of inflammation in vitro.

Material and methods. Hydrocortisone and eugenol leaching from Endomethasone $\mathrm{N}$ and Pulp Canal Sealer (PCS) were quantified by ELISA and spectrofluorometry respectively. The effects of Endomethasone N and Pulp Canal Sealer were studied on Lipopolysaccharides (LPS)-stimulated human periodontal ligament (hPDL) cells. Cytokine (IL-6, TNF- $\alpha$ ) secretion from cells was quantified by ELISA. Inflammatory cell (THP-1) adhesion to activated endothelial cells, their migration and activation were studied in vitro.

Results. Endomethasone N decreased secretion of IL-6 and TNF- $\alpha$ from hPDL cells. THP-1 adhesion to activated endothelial cells (HUVECs) and migration significantly decreased with Endomethasone N while no effect was observed with PCS. Activation of THP-1 decreased with both materials' extracts but was significantly lower with Endomethasone $\mathrm{N}$ than with PCS.

Conclusion. These results performed in vitro show that Endomethasone $\mathrm{N}$ anti-inflammatory effects are due to the presence of hydrocortisone.

Clinical Relevance. The presence of hydrocortisone in Endomethasone $\mathrm{N}$ is responsible for its local anti-inflammatory effects. 


\section{Introduction}

Localized periapical lesions consecutive to bacterial infection of the root canal system are frequently reported [1]. Initiating the host inflammatory reaction is essential to prevent bacterial proliferation in the periapical tissues [2]. The cellular response of inflammation implies immune cell recruitment. Cells such as neutrophils and monocytes adhere to the activated vascular endothelium and, following a chemotaxis gradient, migrate to the injury site where can be activated into macrophage-like cells [3]. After activation, they carry out phagocytosis of dead cell debris and pathogens.

Many cytokines such as interleukins and growth factors are involved in the inflammatory events. Human periodontal ligament (hPDL) cell are known to secrete pro-inflammatory cytokines locally such as Interleukine 6 (IL-6) and Tumor necrosis factor (TNF $\alpha$ ) [4-6]. IL-6 trans-signaling leads to the immune response activation by inducing monocytes recruitment to the inflamed area, inhibition of T-cells apoptosis and differentiation [7]. TNF $\alpha$ is considered as a major inflammatory mediator. It is synthesized in response to the presence of a variety of bacteria and bacterial products, especially lipopolysaccharides. The local cellular effects of TNF $\alpha$ include the capacity to induce vasodilatation through the superoxide burst to allow polymorphonuclear leukocytes to bind to vascular endothelium and activate phagocytosis [8]. It should be reminded however that the inflammatory reaction has some tissue deleterious effects as it may induce the destruction of periodontal tissues. Indeed, a large number of molecules, involved in the inflammatory reaction such as prostaglandins, bacterial endotoxins and Complement molecules or pro-inflammatory cytokines, has been reported to activate bone resorption by osteoclasts $[9,10]$.

The root canal treatment is considered as the most effective and conservative method for treating periapical lesions. Endodontic treatment is achieved not only after canal shaping, disinfection and canal hermetic sealing to prevent the canal reinfection, but also when the 
periapical tissue is regenerated [11]. Following the root canal filling, an interaction frequently potentially alveolar bone, leading to an initial inflammation and subsequent regeneration [12]. These processes are highly dependent on the inflammation arrest. Moreover, it has been shown that dental materials can modulate the inflammatory reaction through modulation of cytokine secretion [13]. Thus, the therapeutic success depends not only on the endodontic treatment, but also on the ability of the host to resolve the inflammatory response [14-16].

Zinc oxide eugenol sealers (ZOE) have been successfully used since decades for root canal filling in combinaison with Gutta Percha. These sealers are known to have good sealing properties and antimicrobial activity. But they have prolonged setting time, a high solubility [17] and cytotoxic effects to the periodontal cells [18]. ZOE sealers are also widely used for their reported anti-inflammatory effects due to eugenol. Yet, eugenol effects on dental tissues are controversial [19]. Furthermore, a localized inflammation with zinc oxide eugenol sealers has been observed, both in soft tissue and in the bone [20].

Pulp Canal Sealer (PCS) (SybronEndo, Orange, CA, USA) and Endomethasone N (Septodont, Saint-Maur-des-Fossés, France) are Zinc oxide eugenol sealers. Howerver, Endomethasone $\mathrm{N}$ also contains hydrocortisone (Table 1). This work was designed to determine the influence of these sealers : 1) on human periodontal ligament cell proinflammatory cytokine production ; 2) on the initial steps of inflammation and 3) to investigate the effect of the presence of hydrocortisone on these events. Extracts of the above mentioned sealers were applied on lipopolysaccharide (LPS)-stimulated hPDL cells. The inflammatory response of hPDL cells was investigated through the secretion of proinflammatory cytokines and by investigating their effects on inflammatory cell migration, adhesion, and pro-inflammatory activation of monocytes/macrophages. 


\section{MATERIALS AND METHODS}

\section{Reagent}

Media, reagents and cell culture supplies were from Dutscher (Brumath, France).

\section{Primary Periodontal Ligament Cell Cultures}

hPDL cells were prepared from immature third molars, freshly extracted for orthodontics reasons in compliance with French legislation (informed patient consent and institutional review board approval of the protocol used), by the explant outgrowth method [21]. The teeth were obtained from three different donors for each experiment (4 molars/donor). Cells were cultured in minimum essential medium (MEM) supplemented with $10 \%$ fetal bovine serum, glutamine $2 \mathrm{mM}$, penicillin $100 \mathrm{UI} / \mathrm{mL}$, streptomycin $100 \mu \mathrm{m} / \mathrm{mL}$, and amphotericin B $0.25 \mu \mathrm{g} / \mathrm{mL}$, at $37^{\circ} \mathrm{C}$ in a $95 \%$ air $5 \% \mathrm{CO} 2$ atmosphere. The same culture medium was used for further experimentation but without serum.

\section{Material extract preparation}

Samples of Endomethasone $\mathrm{N}$ and Pulp Canal Sealer were prepared according to the manufacturers' instructions. Each sample was incubated in serum-free MEM 24 hours at $37^{\circ} \mathrm{C}$ to obtain unset materials extracts $(20 \mathrm{mg} / \mathrm{mL})$. The resulting material extracts were filtered on $0.22 \mu \mathrm{m}$ filters. Hydrocortisone was solubilized in DMSO at $100 \mathrm{mM}$, diluted to $1 \mathrm{mM}$ in serum-free MEM and incubated at $37^{\circ} \mathrm{C}$ for 24 hours. Eugenol was solubilized in DMSO at $6 \mathrm{M}$, diluted at $100 \mathrm{mM}$ in serum-free MEM and incubated at $37^{\circ} \mathrm{C}$ for 24 hours. The four conditioned media were diluted in serum-free MEM to obtain the working concentration in the next steps of the experimental protocol. 
Quantitative determination of hydrocortisone and eugenol concentrations in the

Hydrocortisone concentration from samples of Endomethasone N and PCS extracts (20 $\mathrm{mg} / \mathrm{ml}$ ) was determined by enzyme immunoassay according to the manufacturer's instructions (Parameter Hydrocortisone Assay; R\&D Systems).

Eugenol concentration from samples of Endomethasone $\mathrm{N}$ and PCS extracts $(20 \mathrm{mg} / \mathrm{ml})$ was determined by spectrofluorimetry as described [22].

\section{Material extract toxicity}

hPDL cells were cultured at confluency in 96-well plates. The cells were stimulated with LPS $(1 \mu \mathrm{g} / \mathrm{mL})$ for $4 \mathrm{~h}$ and incubated either with the materials extracts $(20 / 2 / 0.2 \mathrm{mg} / \mathrm{mL})$, eugenol $(10 / 1 / 0.1 \mu \mathrm{M})$, hydrocortisone $(100 / 10 / 1 \mu \mathrm{M})$ or serum-free MEM control media. After 24h, the supernatants were removed and MTT test (Sigma-Aldrich, St Louis, MO) was performed with the MTT substrate (3-(4,5-dimethylthiazol-2-yl)-2,5-diphenyltetrazolium bromide) as described [23].

\section{Cytokine secretion by hPDL cells}

hPDL cells were cultured at confluency in 12-well plates. Cells were stimulated for $4 \mathrm{~h}$ with LPS $(1 \mu \mathrm{g} / \mathrm{ml})$ and incubated with material extract $(0.2 \mathrm{mg} / \mathrm{mL})$, eugenol $(0.1 \mu \mathrm{M})$, hydrocortisone $(1 \mu \mathrm{M})$ or serum-free MEM control media. After $24 \mathrm{~h}$ the supernatants were used for pro-inflammatory (IL- 6 and TNF- $\alpha$ ) cytokines quantification by the enzyme-linked immunosorbent assay (ELISA) using Duoset kits (R\&D Systems) according to the manufacturer's instructions.

\section{THP-1 cell recruitment sequence}


$\underline{\text { Human umbilical vein endothelial cells (HUVECs) and inflammatory THP-1 cells culture }}$

HUVECs (PromoCell, Heidelberg, Germany) were cultured in Endothelial Cell Growth Medium 2 (ECGM 2, PromoCell). THP-1 cells, a human monocytic cell line (Sigma, St Quentin Fallavier, France) were cultured in RPMI medium supplemented (10\% FBS, 100UI/mL Penicillin, $100 \mu \mathrm{g} / \mathrm{mL}$ streptomycin, $0,25 \mu \mathrm{g} / \mathrm{mL}$ amphotericin B, $2 \mathrm{mM} \mathrm{L-}$ glutamine, $1 \mathrm{mM}$ sodium pyruvate), as described [13].

$\underline{\text { THP-1 cell adhesion on endothelial cells }}$

hPDL cells were cultured at confluency in 12-well plates. Cells were stimulated for $4 \mathrm{~h}$ with LPS $(1 \mu \mathrm{g} / \mathrm{ml})$ and incubated with material extract $(0.2 \mathrm{mg} / \mathrm{mL})$, eugenol $(0.1 \mu \mathrm{M})$, hydrocortisone $(1 \mu \mathrm{M})$ or serum-free MEM control media. After $24 \mathrm{~h}$, the supernatant was recovered and called conditioned medium.

Confluent HUVECs $\left(80000\right.$ cells $\left./ \mathrm{cm}^{2}\right)$, in 12-well plates, were cultured with conditioned medium for $4 \mathrm{~h}$ at $37^{\circ} \mathrm{C}$. THP- 1 cells were first incubated with $0.1 \mu \mathrm{M}$ of BCECF acid (2',7'-Bis-(2-Carboxyethyl)-5-(and-6)-Carboxyfluorescein) for 1h. BCECF-labeled THP1 cells $(25000$ cells $/ \mathrm{mL})$ were then added to the HUVECs monolayers for 30 min at $4{ }^{\circ} \mathrm{C}$ under gentle orbital rotation as described [24]. HUVECs were then washed four times with Phosphate Buffered Saline with calcium and magnesium (PBS) and THP-1 adherent cells were counted in 5 random fields using a fluorescent microscope (X100). Results are express as percentage of the control.

\section{$\underline{\text { THP-1 cell migration }}$}

Cell migration was assayed with Boyden chambers ( $8 \mu \mathrm{m}$ pore size $)$ in 12 -well plates. Confluent hPDL cells, cultured in the lower chambers, were stimulated with LPS $(1 \mu \mathrm{g} / \mathrm{ml})$ for 4 hours and then incubated with material extract $(0.2 \mathrm{mg} / \mathrm{mL})$, eugenol $(0.1 \mu \mathrm{M})$, 
hydrocortisone $(1 \mu \mathrm{M})$ or serum-free MEM control media for $24 \mathrm{~h}$. THP-1 cells were activated with Phorbol Myristate Acetate (PMA 400ng/mL, 24h) and seeded (15000 cells /100 $\mu$ l) in the upper chambers. After migration for 24 hours, THP-1 cells on the top side of the filter were wiped off using a cotton bud, and cells that migrated to the lower surface of the filter were fixed (15min, cold ethanol $70 \%$ ) and stained with eosin (20min). The number of migrating cells to the lower surface of the filter membrane was counted in 5 random fields using light microscopy (X100). Results are expressed as percentage of control.

\section{$\underline{\text { THP-1 cell activation }}$}

hPDL cells were cultured at confluency in 12-well plates. Cells were stimulated for $4 \mathrm{~h}$ with LPS $(1 \mu \mathrm{g} / \mathrm{ml})$ and incubated with material extract $(0.2 \mathrm{mg} / \mathrm{mL})$, eugenol $(0.1 \mu \mathrm{M})$, hydrocortisone $(1 \mu \mathrm{M})$ or serum-free MEM control media. After $24 \mathrm{~h}$, the supernatant was recovered and called conditioned medium.

THP-1 suspension (25000 cells/mL) was cultured with hPDL cells conditioned medium in 12 well plates for $24 \mathrm{~h}$. Then, the wells were washed four times with PBS to remove not activated and dead cells. Adherent cells were fixed (15min, cold ethanol $70 \%)$ and nuclei stained with DAPI (4',6-diamidino-2-phenylindole) $(1 \mu \mathrm{g} / \mathrm{ml})$. The number of activated (adherent) cells was counted in 5 random fields using a fluorescent microscope (X100). Results are express as percentage of the control.

\section{Statistical analysis}

All experiments were done in triplicate and repeated three times. Data are expressed as means \pm standard error of mean. Student t-test was used to determine statistical significance ( $p$-value $<0.05)$. 


\section{RESULTS}

Quantitative determination of hydrocortisone and eugenol concentration in the sealers extracts

After $24 \mathrm{~h}$ of incubation of sealers samples at $37^{\circ} \mathrm{C}, 85 \pm 9.9 \mu \mathrm{M}$ of hydrocortisone was released from Endomethasone $\mathrm{N}(20 \mathrm{mg} / \mathrm{ml})$ in serum-free MEM medium (Fig. 1A). No hydrocortisone was detected with PCS.

After $24 \mathrm{~h}$ of incubation of sealers samples at $37^{\circ} \mathrm{C}, 10 \pm 1.6 \mu \mathrm{M}$ of eugenol was released from Endomethasone $\mathrm{N}(20 \mathrm{mg} / \mathrm{ml})$ and $10 \pm 2.0 \mu \mathrm{M}$ from PCS $(20 \mathrm{mg} / \mathrm{ml})$ in serum-free MEM medium (Fig. 1A).

\section{Endodontics sealer extracts toxicity}

LPS-stimulated hPDL cell viability decreased significantly after $24 \mathrm{~h}$ of contact with the medium containing Endomethasone $\mathrm{N}$ and PCS extracts at 20mg/ml, $100 \mu \mathrm{M}$ of hydrocortisone and $10 \mu \mathrm{M}$ of eugenol as compared to the control medium (Fig. 1B). PCS also induce a significant decrease in cell viability at $2 \mathrm{mg} / \mathrm{ml}$.

No statistically significant effect was observed on hPDL cells viability with $0.2 \mathrm{mg} / \mathrm{ml}$ sealers extract, $1 \mu \mathrm{M}$ hydrocortisone and $0.1 \mu \mathrm{M}$ eugenol (Fig. 1B) compared to the control. These non-toxic working concentrations were chosen for next step.

\section{Endodontics sealers modified cytokine secretion}

Applying hydrocortisone, eugenol and Endomethasone $\mathrm{N}$ for $24 \mathrm{~h}$, led to a significant decrease of the pro-inflammatory IL- 6 and TNF- $\alpha$ secretion. PCS induced a significantly higher secretion of IL-6 but had no effect on TNF- $\alpha$ compared to control condition (Fig. 2).

\section{Inflammatory cell recruitment modulation}


Inflammatory THP-1 cell adhesion on HUVECs monolayer assay is illustrated with representative picture used for cell counts (Fig. 3A). THP-1 adhesion significantly decreased with hydrocortisone and Endomethasone $\mathrm{N}$ while no effect was observed with PCS and eugenol compared to control condition (Fig. 3B). THP-1 cell migration significantly decreased only with hydrocortisone and Endomethasone $\mathrm{N}$ extracts (Fig. 4). Inflammatory THP-1 cells activation assay is illustrated with representative pictures used for cell counts (Fig. 5A). This activation decreased with all materials extracts but was significantly lower with hydrocortisone and Endomethasone $\mathrm{N}$ as compared to PCS and eugenol (Fig. 5B). 


\section{DISCUSSION}

This work shows that, after simulating hPDL cell bacterial infection, applying endodontics sealers on these cells affects the local inflammatory response. It demonstrates the efficiency of hydrocortisone-containing root canal sealer (Endomethasone $\mathrm{N}$ ) in modulating the initial steps of inflammation.

ZOE sealers have been widely used in root canal treatment because of their handling properties, reasonable cost, excellent sealing ability and therapeutic effects including sedative, antibacterial and anti-inflammatory effects [25]. However, ZOE have some drawbacks such as cytotoxicity and harm to surrounding periodontal tissues [26].

During endodontic obturation with gutta-percha, the unset endodontic sealer may exceed the root apex and release substances that could reach and interact with inflamed periodontal tissues. To simulate, in vitro, this clinical situation, hPDL cells were stimulated with LPS and then cultured in contact with endodontics sealers extracts (Endomethasone N and PCS). Our results confirmed a high toxicity of zinc-oxide eugenol sealers at $20 \mathrm{mg} / \mathrm{ml}$. This is consistent with previous works showing the toxicity of PCS $[27,28]$. However, none of the two root canal sealers or eugenol used alone had cytotoxic effects at the lowest concentration on stimulated hPDL cells. After hydrolysis in water, these sealers release zinc hydroxide and eugenol. Eugenol is derived from essential oil which is known for its anti-microbial, antiinflammatory and anti-oxidant properties which have been evaluated in a variety of models $[29,30]$.

To investigate the effect of Endomethasone $\mathrm{N}$ and PCS on modulating the inflammatory response of hPDL cells, we first quantified eugenol and hydrocortisone release from the sealers. Our results show that PCS and Endomethasone N released the same concentration of eugenol. But hydrocortisone was released only from Endomethasone N. Then we used equivalent concentrations of eugenol and hydrocortisone to link our findings to those obtained 
after leaching from the sealers. Our work show that Endomethasone N, hydrocortisone and

Thus our data confirm eugenol anti-inflammatory potential when used alone while these effects are not observed in PCS extracts. This result is in agreement with a previous investigation on ZOE sealers where Intermediate Restorative Material and Tubli-Seal sealers extracts were compared to eugenol anti-inflammatory effects [31]. When eugenol was used alone, it was found to inhibit inflammatory mRNA gene expression in LPS-pre-treated mouse bone marrow monocytes while these effects were not observed in the sealers extracts. This was also demonstrated with the use of the $\mathrm{C} 3$ cross immunoelectrophoretic technique where complement system activation was stimulated with $\mathrm{N} 2 / \mathrm{RC} 2 \mathrm{~B}$ root canal sealer and eugenol [32]. This suggests that the anti-inflammatory effect of Endomethasone $\mathrm{N}$ observed in our work can be attributed to hydrocortisone but not to eugenol.

We further confirmed these results on cytokine secretion by investigation of the antiinflammatory effect of hydrocortisone containing material through adhesion of inflammatory cells on the activated endothelium, their migration towards the stimulated cells, and their activation. Even if neutrophils are strongly recruited in vivo, monocytes, such THP-1 have been used to study of the inflammation in vitro [33]. Co-culture of THP-1 cells with HUVEC model has been also used to study inflammatory cell adhesion [34, 35]. Incubating LPSstimulated hPDL cells with PCS extract and eugenol did not affect THP-1 adhesion on HUVEC monolayer or their migration but significantly decreased their activation. However, when hPDL cells were stimulated with LPS and incubated with hydrocortisone or Endomethasone N, the number of migrated/activated THP-1 cells as well as THP-1 cell adhesion on HUVEC monolayer drastically decreased. In our study, the anti-inflammatory effect of eugenol on cytokine secretion was not observed while that of hydrocortisone was confirmed at the cellular level. In line with these finding, the inflammatory effects of eugenol 
have been well demonstrated in vivo by investigating two ZOE sealers (Sargenti N2 and over a 6-month period [36], both ZOE sealers led to a severe irritation over the full 6-month duration. Other in vivo studies have reported prolonged irritation effect of EndoFill, another hydrocortisone containing ZOE sealer [37]. On the other hand it has been shown that the subcutaneous tissue inflammation reactions to Endomethasone $\mathrm{N}$ decreased rapidly with time. This might be due to hydrocortisone local liberation [38, 39].

Taken together, these results performed in vitro show that Endomethasone $\mathrm{N}$ has antiinflammatory effects. Our results show that this effect is due to the presence of hydrocortisone rather than eugenol in Endomethasone N. 


\section{Figure Legends}

\section{Figure 1:}

\section{(A) Quantification of hydrocortisone and eugenol concentrations in the materials}

extracts. The quantification of hydrocortisone was performed using the ELISA assay and eugenol by spectrophotometry. After $24 \mathrm{~h}$ of incubation at $37^{\circ} \mathrm{C}, 85 \pm 9.9 \mu \mathrm{mol} / \mathrm{L}$ of hydrocortisone was released from Endomethasone $\mathrm{N}(20 \mathrm{mg} / \mathrm{ml})$ in serum-free MEM media. No hydrocortisone was detected in PCS extracts or in the control condition. Eugenol was detected in Endomethasone N $(10 \pm 1.6 \mu \mathrm{mol} / \mathrm{L})$ and PCS $(10 \pm 2.0 \mu \mathrm{mol} / \mathrm{L})$ extracts.

(B) Cell Viability after contact with the materials extracts. A significant decrease in hPDL cell viability was observed after $24 \mathrm{~h}$ of contact with the media containing Endomethasone $\mathrm{N}$ and PCS extracts $(20 \mathrm{mg} / \mathrm{ml})$, hydrocortisone $(100 \mu \mathrm{M})$ and eugenol $(10 \mu \mathrm{M})$ as compared to the control medium. A significant decrease in cell viability was observed with PCS extracts at $2 \mathrm{mg} / \mathrm{ml}$.

No statistically significant effect was observed in hPDL cell viability with both sealer extracts at $0.2 \mathrm{mg} / \mathrm{ml}, 1 \mu \mathrm{M}$ hydrocortisone nor $0.1 \mu \mathrm{M}$ of eugenol as compared to the control. Results are expressed in percentage of the control. (*) corresponds to significant differences as compared to the control ( $\mathrm{p}$-value $<0.05)$.

\section{Figure 2: Effects of sealers on cytokine secretion}

A significant increase of IL-6 secretion by LPS stimulated hPDL cells was observed after $24 \mathrm{~h}$ of incubation with PCS. This secretion significantly decreased with hydrocortisone, eugenol and Endomethasone N. A significant decrease in TNF- $\alpha$ secretion was also observed with hydrocortisone and Endomethasone $\mathrm{N}$ as compared to the control and PCS. 
Results are expressed in $\mathrm{pg} / \mathrm{mL}(*)$ corresponds to significant difference as compared to the control, $(* *)$ represents significant differences between two conditions ( $\mathrm{p}$-value $<0.05)$.

\title{
Figure 3: Inflammatory THP-1 adhesion on endothelial cells (HUVECs)
}

(A) Representatives pictures on fluorescent microscopy of the adhesion assay of BCECF labelled THP-1 cells on endothelial cells for (a) control; (b) eugenol; (c) hydrocortisone; (d)

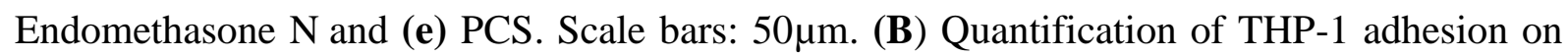
endothelial cells. Hydrocortisone and Endomethasone N extract significantly decreased THP1 cell adhesion on HUVECs compared to eugenol, PCS and to the control. Results are expressed in percentage of the control. $(*)$ corresponds to significant differences as compared to the control; $(* *)$ represents significant differences between two conditions ( $\mathrm{p}$-value $<0.05$ ).

\section{Figure 4: THP-1 cell migration in Boyden chambers}

\begin{abstract}
(A) Schematic representation of Boyden chamber migration assay (B) Migration assay in Boyden chambers after 24 hours showed that hydrocortisone and Endomethasone $\mathrm{N}$ significantly reduced inflammatory THP-1 cell migration towards LPS-stimulated hPDL cells. This migration was not affected by PCS or eugenol.
\end{abstract}

\section{Figure 5: THP-1 cell activation}

(A) Representative pictures on fluorescent microscopy of THP-1 activation assay showing THP-1 activated cells after their incubation with material extracts for 24 hours. (a) control; (b) eugenol; (c) hydrocortisone; (d) Endomethasone N and (e) PCS. Scale bars: $200 \mu \mathrm{m}$. (B) Quantification of THP-1 activation. THP-1 cell activation was significantly reduced by hydrocortisone and Endomethasone $\mathrm{N}$ and to a lesser extent by PCS and eugenol. Results are 
expressed in percentage of control, $(*)$ corresponds to significant difference as compared to the control; $(* *)$ represents significant differences between two conditions ( $\mathrm{p}$-value $<0.05$ ). 


\section{Bibliography}

1. Nair PNR (2006) On the causes of persistent apical periodontitis: a review. International Endodontic Journal 39:249-281. https://doi.org/10.1111/j.1365-2591.2006.01099.x

2. Childs DR, Murthy AS (2017) Overview of Wound Healing and Management. Surg Clin North Am 97:189-207. https://doi.org/10.1016/j.suc.2016.08.013

3. Ley K, Laudanna C, Cybulsky MI, Nourshargh S (2007) Getting to the site of inflammation: the leukocyte adhesion cascade updated. Nat Rev Immunol 7:678-689. https://doi.org/10.1038/nri2156

4. Ogura N, Shibata Y, Kamino Y, et al (1994) Stimulation of interleukin-6 production of periodontal ligament cells by Porphyromonas endodontalis lipopolysaccharide. Biochem Med Metab Biol 53:130-136

5. Andrukhov O, Andrukhova O, Hulan U, et al (2014) Both 25-hydroxyvitamin-D3 and 1,25-dihydroxyvitamin-D3 reduces inflammatory response in human periodontal ligament cells. PLoS ONE 9:e90301. https://doi.org/10.1371/journal.pone.0090301

6. Cai Z, Falkensammer F, Andrukhov O, et al (2016) Effects of Shock Waves on Expression of IL-6, IL-8, MCP-1, and TNF- $\alpha$ Expression by Human Periodontal Ligament Fibroblasts: An In Vitro Study. Med Sci Monit 22:914-921

7. Romano M, Sironi M, Toniatti C, et al (1997) Role of IL-6 and its soluble receptor in induction of chemokines and leukocyte recruitment. Immunity 6:315-325

8. Ebersole JL, Cappelli D (2000) Acute-phase reactants in infections and inflammatory diseases. Periodontol 2000 23:19-49

9. Stashenko P, Teles R, D'Souza R (1998) Periapical inflammatory responses and their modulation. Crit Rev Oral Biol Med 9:498-521

10. Kawashima N, Stashenko P (1999) Expression of bone-resorptive and regulatory cytokines in murine periapical inflammation. Arch Oral Biol 44:55-66

11. Grossman LI, Oliet S, Del Rio CE (1989) Endodontic practice, 11th ed. Journal of Oral and Maxillofacial Surgery 47:104. https://doi.org/10.1016/0278-2391(89)90159-6

12. Saxena P, Gupta SK, Newaskar V (2013) Biocompatibility of root-end filling materials: recent update. Restor Dent Endod 38:119-127.

https://doi.org/10.5395/rde.2013.38.3.119

13. Giraud T, Jeanneau C, Bergmann M, et al (2018) Tricalcium Silicate Capping Materials Modulate Pulp Healing and Inflammatory Activity In Vitro. J Endod. https://doi.org/10.1016/j.joen.2018.06.009

14. Alexander MB, Damoulis PD (1994) The role of cytokines in the pathogenesis of periodontal disease. Curr Opin Periodontol 39-53

15. Page RC, Kornman KS (1997) The pathogenesis of human periodontitis: an introduction. Periodontol 2000 14:9-11 
16. Di Benedetto A, Gigante I, Colucci S, Grano M (2013) Periodontal disease: linking the primary inflammation to bone loss. Clin Dev Immunol 2013:503754.

https://doi.org/10.1155/2013/503754

17. Gutmann JL, Rakusin H (1987) Perspectives on root canal obturation with thermoplasticized injectable gutta-percha. International Endodontic Journal 20:261-270. https://doi.org/10.1111/j.1365-2591.1987.tb00625.x

18. Jagtap P, Shetty R, Agarwalla A, et al (2018) Comparative Evaluation of Cytotoxicity of Root Canal Sealers on Cultured Human Periodontal Fibroblasts: In vitro Study. J Contemp Dent Pract 19:847-852

19. Hauman CHJ, Love RM (2003) Biocompatibility of dental materials used in contemporary endodontic therapy: a review. Part 2. Root-canal-filling materials. Int Endod J 36:147-160

20. Yesilsoy C, Koren LZ, Morse DR, Kobayashi C (1988) A comparative tissue toxicity evaluation of established and newer root canal sealers. Oral Surg Oral Med Oral Pathol 65:459-467

21. About I, Bottero MJ, de Denato P, et al (2000) Human dentin production in vitro. Exp Cell Res 258:33-41. https://doi.org/10.1006/excr.2000.4909

22. Abou Hashieh I, Camps J, Dejou J, Franquin JC (1998) Eugenol diffusion through dentin related to dentin hydraulic conductance. Dent Mater 14:229-236

23. Camps J, Jeanneau C, El Ayachi I, et al (2015) Bioactivity of a Calcium Silicate-based Endodontic Cement (BioRoot RCS): Interactions with Human Periodontal Ligament Cells In Vitro. J Endod 41:1469-1473. https://doi.org/10.1016/j.joen.2015.04.011

24. Mannori G, Crottet P, Cecconi O, et al (1995) Differential colon cancer cell adhesion to E-, P-, and L-selectin: role of mucin-type glycoproteins. Cancer Res 55:4425-4431

25. Kwon J-S, Illeperuma RP, Kim J, et al (2014) Cytotoxicity evaluation of zinc oxideeugenol and non-eugenol cements using different fibroblast cell lines. Acta Odontol Scand 72:64-70. https://doi.org/10.3109/00016357.2013.798871

26. Mutoh N, Tani-Ishii N (2011) A biocompatible model for evaluation of the responses of rat periapical tissue to a new zinc oxide-eugenol sealer. Dent Mater J 30:176-182

27. Guigand M, Pellen-Mussi P, Le Goff A, et al (1999) Evaluation of the cytocompatibility of three endodontic materials. J Endod 25:419-423

28. Lee J-H, Lee H-H, Kim K-N, Kim K-M (2016) Cytotoxicity and anti-inflammatory effects of zinc ions and eugenol during setting of ZOE in immortalized human oral keratinocytes grown as three-dimensional spheroids. Dent Mater 32:e93-104. https://doi.org/10.1016/j.dental.2016.01.003

29. Magalhães CB, Riva DR, DePaula LJ, et al (2010) In vivo anti-inflammatory action of eugenol on lipopolysaccharide-induced lung injury. J Appl Physiol 108:845-851. https://doi.org/10.1152/japplphysiol.00560.2009 
30. Bachiega TF, de Sousa JPB, Bastos JK, Sforcin JM (2012) Clove and eugenol in noncytotoxic concentrations exert immunomodulatory/anti-inflammatory action on cytokine production by murine macrophages. J Pharm Pharmacol 64:610-616. https://doi.org/10.1111/j.2042-7158.2011.01440.x

31. Lee J-H, Lee H-H, Kim H-W, et al (2017) Immunomodulatory/anti-inflammatory effect of ZOE-based dental materials. Dent Mater 33:e1-e12. https://doi.org/10.1016/j.dental.2016.09.012

32. Serene TP, Vesely J, Boackle RJ (1988) Complement activation as a possible in vitro indication of the inflammatory potential of endodontic materials. Oral Surg Oral Med Oral Pathol 65:354-357

33. Chanput W, Mes JJ, Wichers HJ (2014) THP-1 cell line: an in vitro cell model for immune modulation approach. Int Immunopharmacol 23:37-45.

https://doi.org/10.1016/j.intimp.2014.08.002

34. Sneddon AA, McLeod E, Wahle KWJ, Arthur JR (2006) Cytokine-induced monocyte adhesion to endothelial cells involves platelet-activating factor: suppression by conjugated linoleic acid. Biochim Biophys Acta 1761:793-801. https://doi.org/10.1016/j.bbalip.2006.05.014

35. Su PM, Jain shil K (2014) Effect of PIP3 on Adhesion Molecules and Adhesion of THP-1 Monocytes to HUVEC Treated with High Glucose. Cell Physiol Biochem 33:1197-1204. https://doi.org/10.1159/000358688

36. Hong YC, Wang JT, Hong CY, et al (1991) The periapical tissue reactions to a calcium phosphate cement in the teeth of monkeys. J Biomed Mater Res 25:485-498. https://doi.org/10.1002/jbm.820250406

37. Christian Gomes Moura C, Cristina Cunha T, Oliveira Crema V, et al (2014) A Study on Biocompatibility of Three Endodontic Sealers: Intensity and Duration of Tissue Irritation. Iran Endod J 9:137-143

38. Kaplan AE, Ormaechea MF, Picca M, et al (2003) Rheological properties and biocompatibility of endodontic sealers. Int Endod J 36:527-532

39. Zafalon EJ, Versiani MA, de Souza CJA, et al (2007) In vivo comparison of the biocompatibility of two root canal sealers implanted into the subcutaneous connective tissue of rats. Oral Surg Oral Med Oral Pathol Oral Radiol Endod 103:e88-94. https://doi.org/10.1016/j.tripleo.2006.11.025 


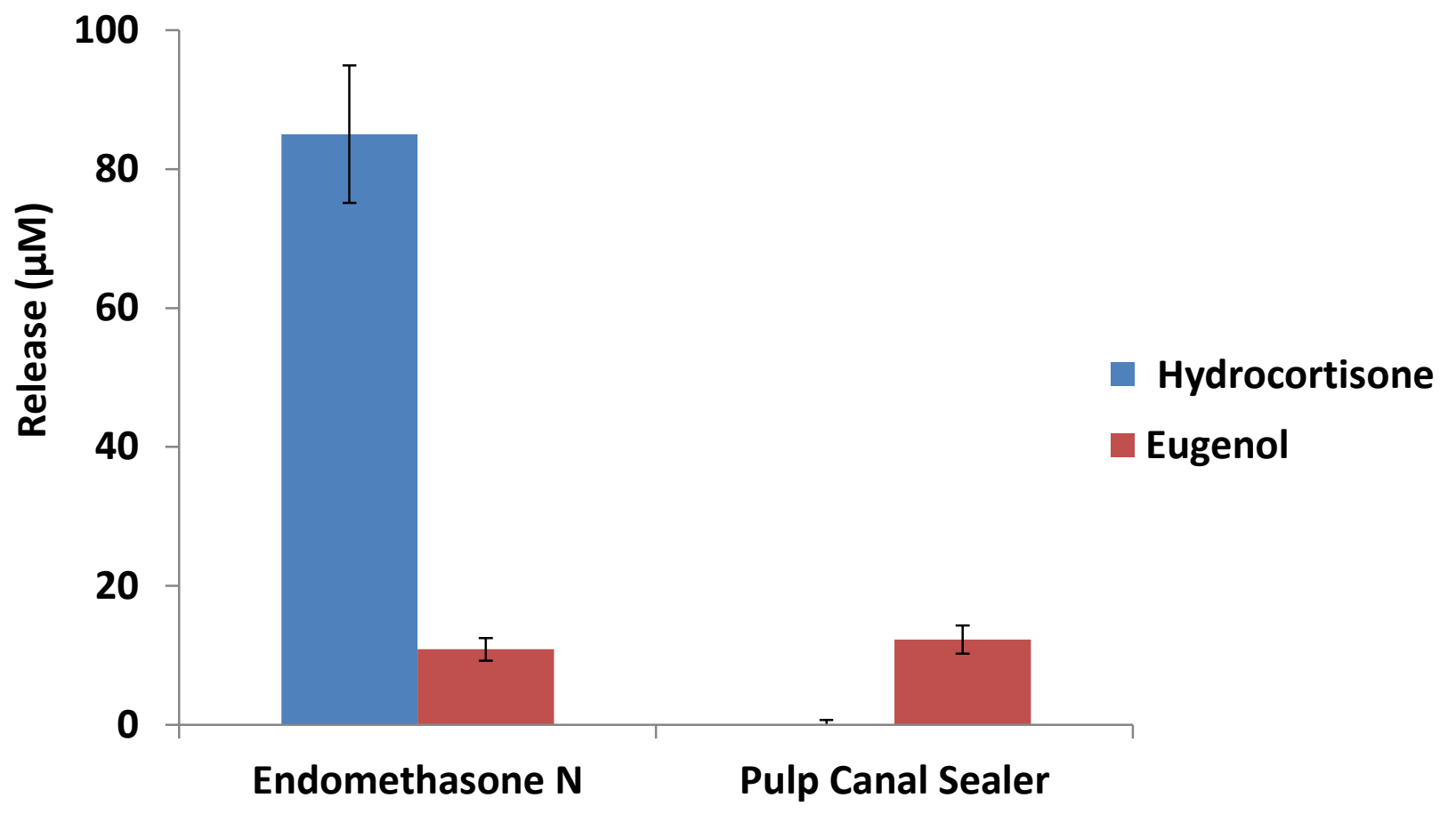

B

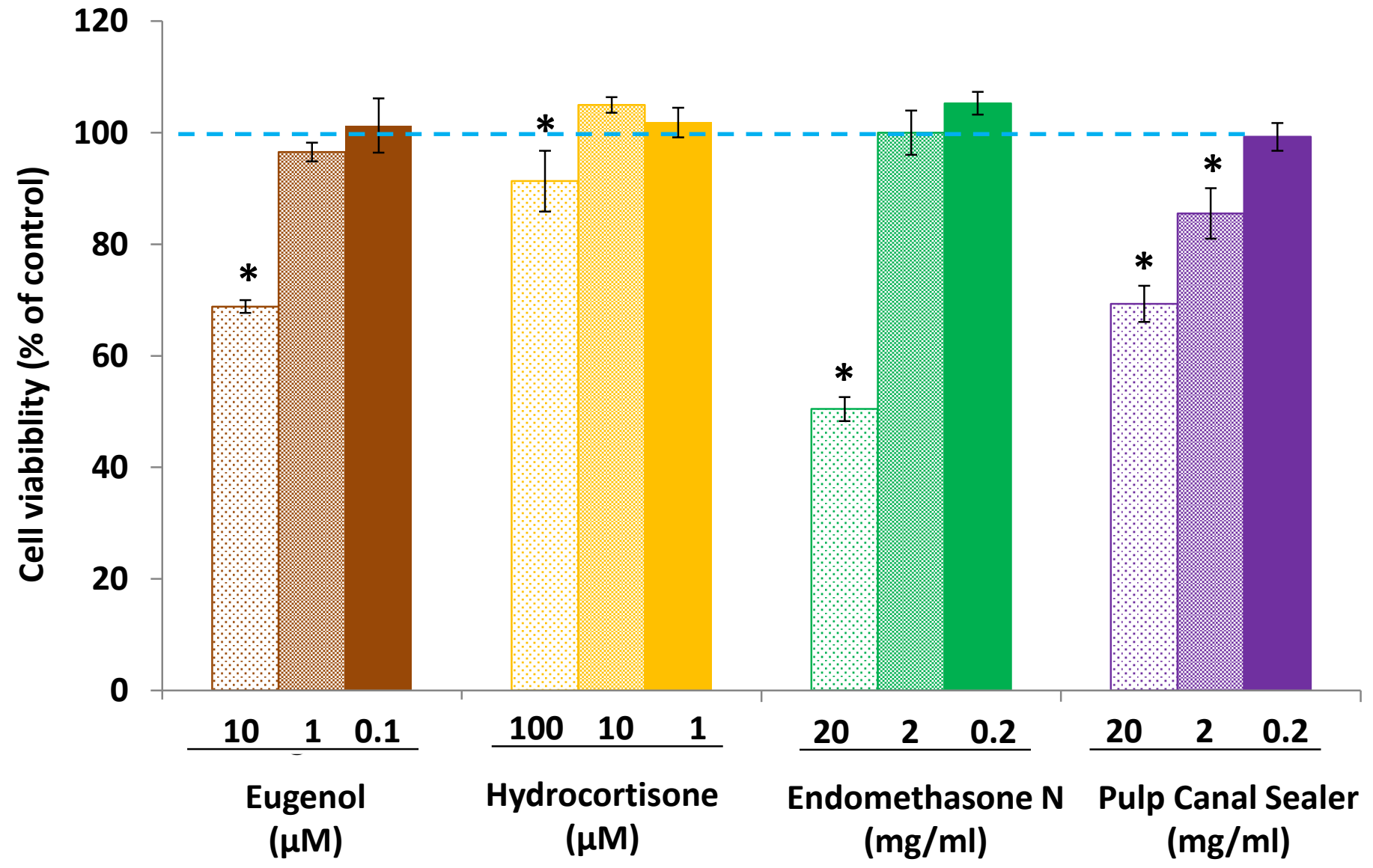




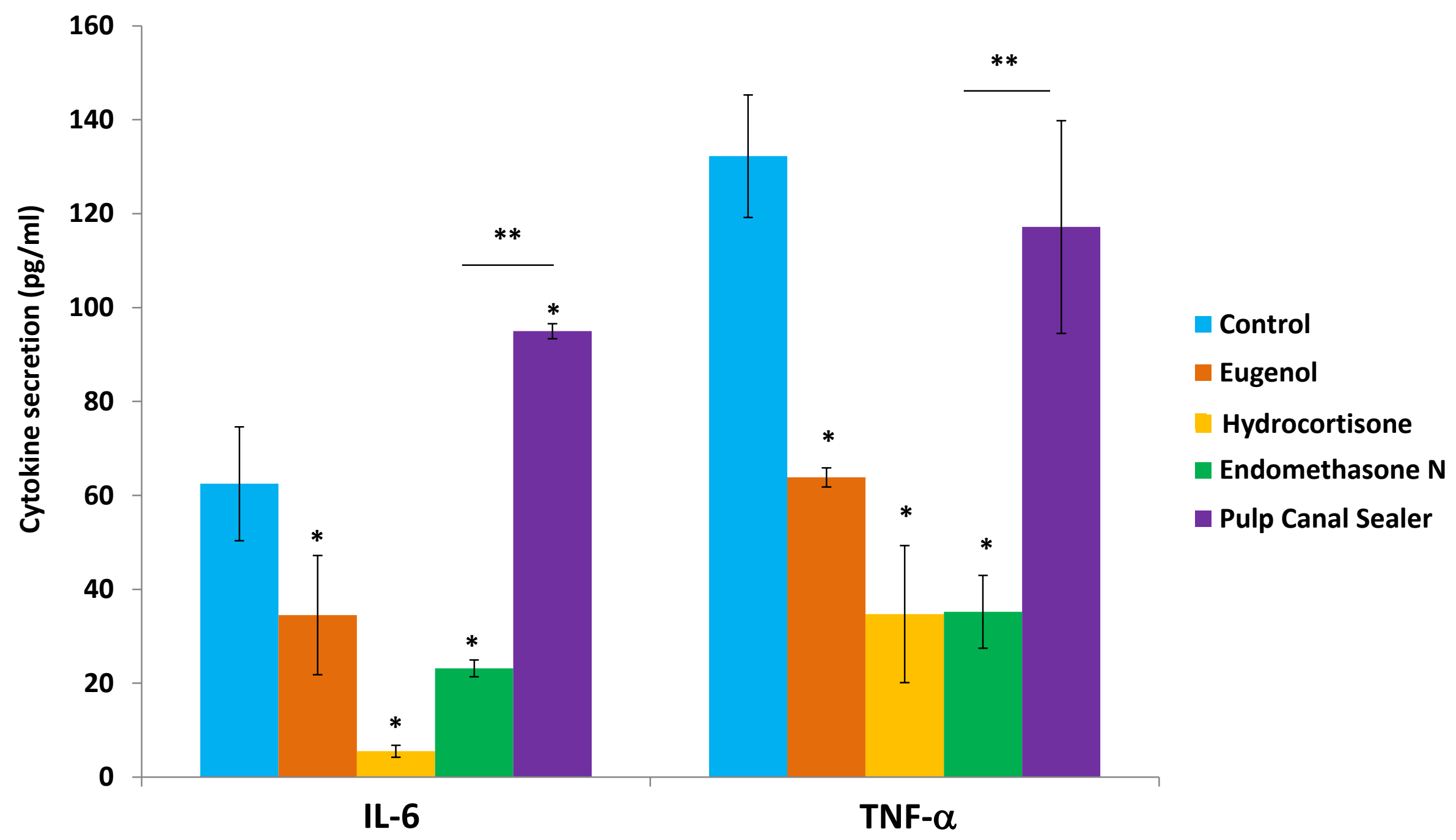



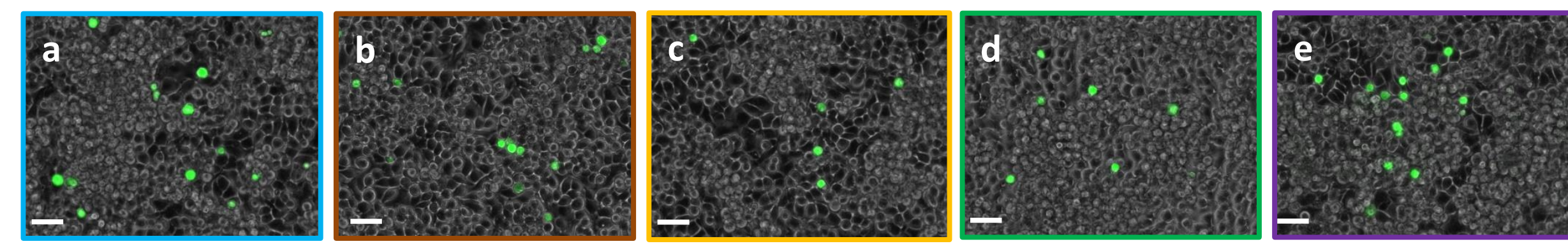

B

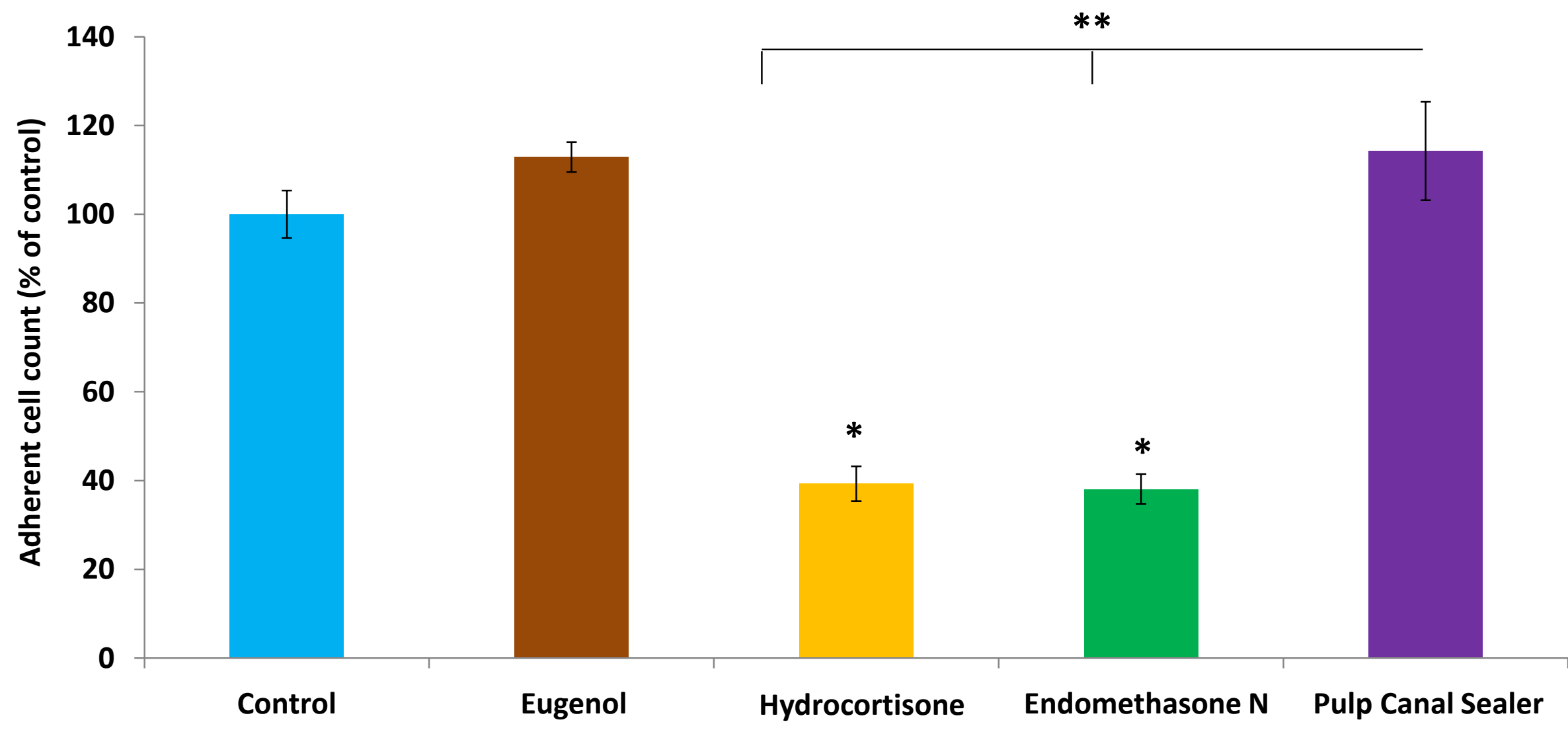



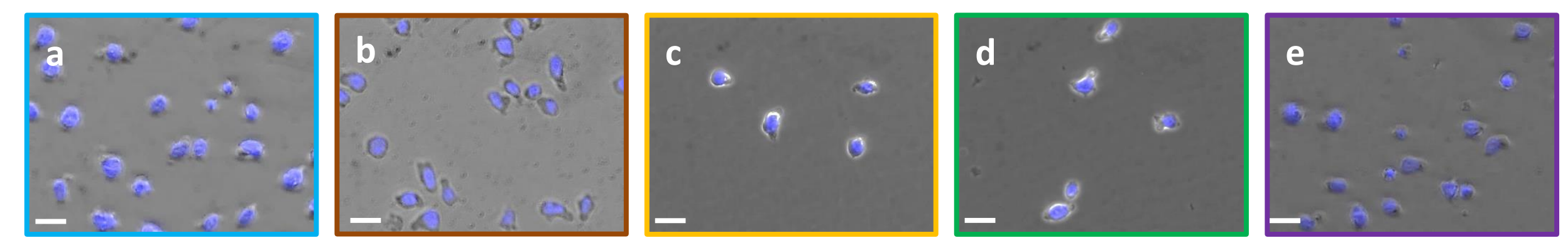

B

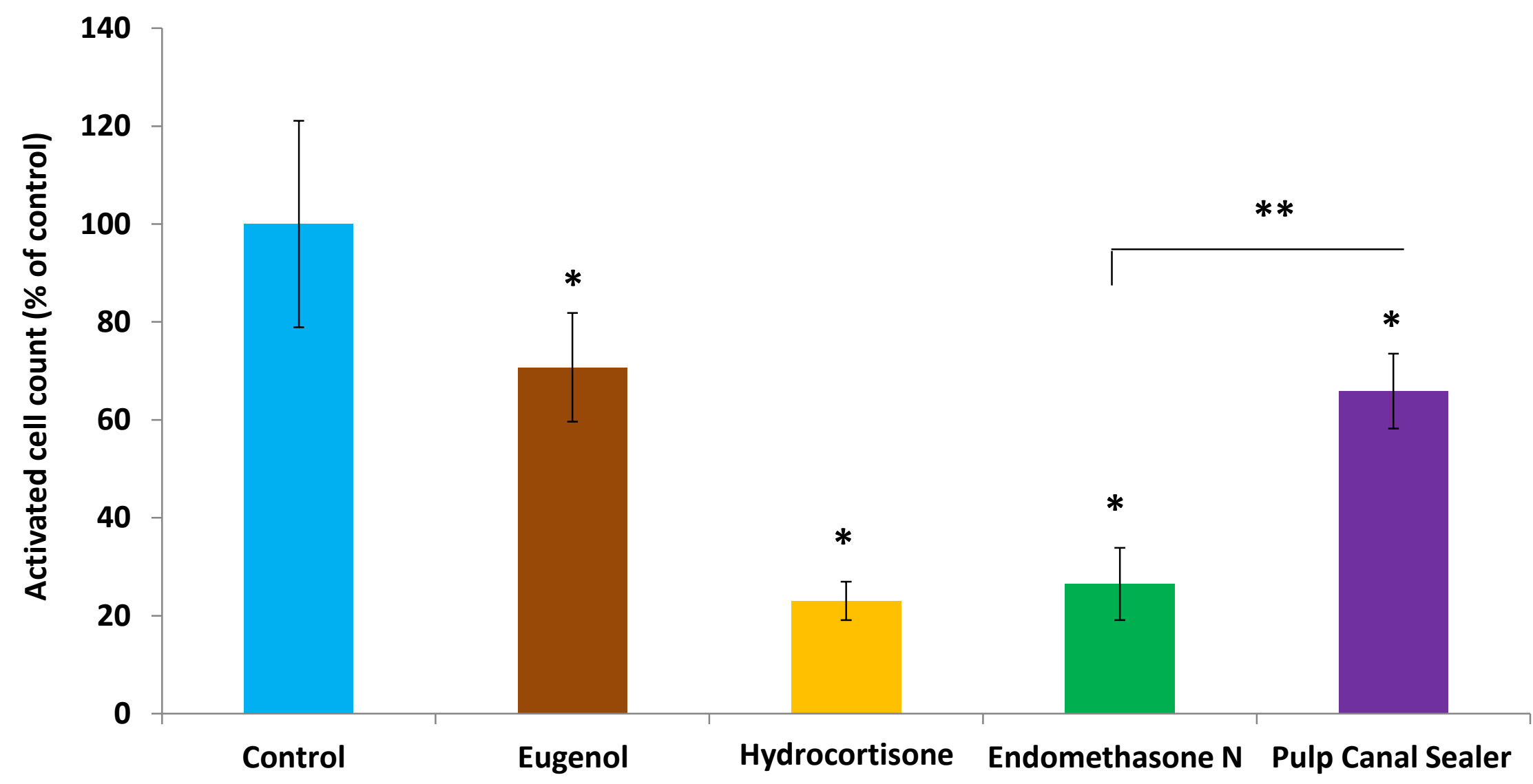




\begin{tabular}{|l|l|l|}
\hline \multicolumn{1}{|c|}{ Endodontic sealer } & \multicolumn{1}{|c|}{ Powder } & \multicolumn{1}{c|}{ Liquid } \\
\hline Endomethasone N & $\begin{array}{l}\text { Hydrocortisone 1\% } \\
\text { Diiodothymol } \\
\text { Barium sulfate 15\% } \\
\text { Zinc oxide } \\
\text { Magnesium stearate }\end{array}$ & Eugenol 100\% \\
\hline Pulp Canal Sealer & $\begin{array}{l}\text { Zinc Oxide 34-41 \% } \\
\text { Precipitated silver 25-30\% } \\
\text { Oleo resins 30-16\% } \\
\text { Thymol iodide 11-12\% }\end{array}$ & $\begin{array}{l}\text { Eugenol 78-80\% } \\
\text { Canada basalm 20-22\% }\end{array}$ \\
\hline
\end{tabular}

TABLE 1: Composition of the sealers used 